\title{
GERMINAÇÃO IN VITRO DE URUCU ${ }^{1}$
}

\author{
RENATA VIANNALIMA ${ }^{2}$, JOSÉ CARLOS LOPES $^{3}$, EDILSON ROMAIS SCHMILDT ${ }^{4}$, ALINE RODRIGUESMAIA $^{5}$
}

\begin{abstract}
RESUMO - Esse trabalho foi realizado com o objetivo de avaliar a germinação de sementes e o desenvolvimento de eixos embrionários de urucu (Bixa orellana L.), cultivar Casca Verde, em meio de cultivo in vitro, com diferentes concentrações de ágar. O delineamento experimental foi o inteiramente casualizado, com quatro repetições, em esquema fatorial Ax B, sendo para o fator A: sementes intactas, sementes sem tegumento e eixos embrionários e para o fator B: quatro níveis de ágar (4, 6, 8 e 10g.L-1) em meio básico "MS". Sementes sem tegumento em meio de cultura contendo $4 \mathrm{~g} \cdot \mathrm{L}^{-1}$ de ágar apresentaram maior porcentagem de germinação. Maiores porcentagens de plântulas normais foram observadas no desenvolvimento de eixos embrionários em meio de cultura contendo $10 \mathrm{~g} \cdot \mathrm{L}^{-1}$ de ágar. Sementes intactas apresentaram as menores porcentagens de germinação e de plântulas anormais em 4 e $6 \mathrm{~g} \cdot \mathrm{L}^{-1}$ de ágar. Maiores massas de matéria fresca e seca das plântulas normais ocorreram na germinação de sementes sem tegumento em meio de cultivo com concentração de $10 \mathrm{~g} \cdot \mathrm{L}^{-1}$ de ágar.
\end{abstract}

Termos para indexação: Bixa orellana, meio de cultura, ágar.

\section{GERMINATION IN VITRO OF ANNATTO SEEDS}

\begin{abstract}
This study was carried with the objective of evaluating the germination of annatto seeds and their embryonic axes development (Bixa orellana L.), cultivating Casca Verde in in vitro culture medium with different agar concentrations. The treatments were set in a completely randomized design, with four replications, in an A x B factorial scheme where factor A consisted of annatto intact seeds (SI), seeds without tegument (SST) and only embryonic axes (E) and factor B consisted of four levels of agar concentrations $\left(4,6,8\right.$ and $\left.10 \mathrm{~g} \mathrm{~L}^{-1}\right)$ in basic medium "MS". Seeds without tegument in culture medium containing $4 \mathrm{~g} \mathrm{~L}^{-1}$ agar presented a greater germination percentage. The largest percentage of normal seedlings was obtained in the development of embryonic axes in culture medium containing $10 \mathrm{~g} \mathrm{~L}^{-1}$ agar. Intact seeds presented the smallest germination values and abnormal seedlings in 4 and $6 \mathrm{~g} \mathrm{~L}^{-1}$ agar. Greater values of fresh and dry weight of normal seedlings occurred in the germination of seeds without tegument in culture medium with concentration of $10 \mathrm{~g} \mathrm{~L}^{-1}$ agar.
\end{abstract}

Index terms: Bixa orellana, culture medium, agar.

\section{INTRODUÇÃO}

Para que a germinação ocorra com eficiência, é necessário que as sementes estejam viáveis, que as condições ambientais sejam favoráveis e que as sementes não estejam dormentes.

\footnotetext{
${ }^{1}$ Submetido em 26/09/2005. Aceito para publicação em 21/11/2006. Parte integrante da dissertação de mestrado pelo primeiro autor.

${ }^{2}$ Mestranda em Produção Vegetal do CCA-UFES. Bolsista CNPq. renatams@cca.ufes.br

${ }^{3}$ Professor orientador do CCA-UFES. Departamento de Fitotecnia.
}

A dormência pode ocorrer devido a diversos fatores, como: embrião imaturo, impermeabilidade do tegumento, presença de inibidores químicos e ausência de promotores de germinação e também exigências especiais de luz ou temperatura (Bewley e Black, 1994), além do efeito inibitório

sementes@cca.ufes.br

${ }^{4}$ Professor co-orientador do CCA-UFES. Departamento de Fitotecnia. edílson@cca.ufes.br

${ }^{5}$ Mestranda em Produção Vegetal do CCA-UFES.
alinerodriguesm@yahoo.com.br 
dos cotilédones (Taiz e Zeiger, 2004).

O urucuzeiro é uma espécie rústica, pouco exigente em tratos culturais e de crescimento rápido (Ramalho et al., 1987). Suas sementes constituem-se na via de propagação mais empregada na implantação dos campos produtores de urucu, sendo classificadas como tégmicas, onde o tégmen é o responsável pela proteção do embrião e de outros tecidos internos e a testa tem a função de secretar corantes (Chopra e Kaur, 1965). Nessa espécie, a maturação das sementes culmina com aumento da impermeabilidade do tegumento à água, mecanismo de dormência imposto pelo tégmen, sendo necessária, então, a escarificação das sementes para que as mesmas germinem (Amaral et al., 1995). Essa escarificação pode ser feita utilizando-se tratamentos especiais como solventes orgânicos (álcool e acetona), ácidos fortes (ácido sulfúrico concentrado), água quente (termoterapia), além do aquecimento a seco e escarificação mecânica, onde se provoca um desgaste no envoltório das sementes (Amaral et al., 1995). Rolston (1978) verificou que, durante o desenvolvimento das sementes desta espécie, o tegumento interno se espessa acentuadamente, atingindo um padrão semelhante ao das leguminosas arbóreas, após a maturação.

O cultivo de embriões possibilita avaliar as necessidades nutricionais para seu desenvolvimento, superar a dormência em certos tipos de sementes, testar a viabilidade das sementes, obter híbridos interespecíficos viáveis, além de aplicar técnicas de duplicação cromossômica in vitro (Pasqual e Pinto, 1988).

Segundo Maciel et al. (2000), a propagação in vitro é uma técnica de cultura de tecidos bem sucedida e propicia vantagens sobre os métodos convencionais de propagação, permitindo a obtenção em curto espaço de tempo e em qualquer época do ano, de um grande número de plantas de boa qualidade fitossanitária e autenticidade vegetal.

Os meios de cultura sólidos ou semi-sólidos são, na maioria das vezes, solidificados com ágar, e a consistência desses meios depende de fatores como qualidade e concentração do ágar, que pode variar de 0,4 a $1 \%$ (Murashige, 1974; Caldas et al., 1998), do pH, não havendo uma formulação-padrão para o cultivo in vitro, sendo, entretanto, utilizado o meio MS (Murashige e Skoog, 1962), com sucesso para diversas espécies (Grattapaglia e Machado, 1998). Para Bixa orellana não foram encontrados trabalhos de cultivo in vitro e que demonstrassem a evolução e os estádios de desenvolvimento dos embriões zigóticos em função do meio e do tempo.

O objetivo desse trabalho foi avaliar a germinação de sementes e o desenvolvimento de eixos embrionários de urucu
(Bixa orellana L.), cultivar Casca Verde, em meio de cultivo in vitro com diferentes concentrações de ágar.

\section{MATERIALE MÉTODOS}

O trabalho foi desenvolvido no Laboratório de Biotecnologia Vegetal do Centro de Ciências Agrárias da Universidade Federal do Espírito Santo (CCA-UFES), em Alegre-ES, de outubro a dezembro de 2004.

Foram utilizadas sementes de urucu (Bixa orellana L.), cultivar Casca Verde, provenientes de plantas com cinco anos de idade, de um mesmo pomar de produção, colhidas em outubro de 2004. Os frutos foram colhidos aleatoriamente, em diversas partes das plantas, antes da deiscência, quando apresentavam a coloração marrom. As sementes foram extraídas manualmente, homogeneizadas, lavadas em água corrente, mantidas sobre papel substrato Germitest ${ }^{\circledR}$ para secagem, à temperatura do ambiente do Laboratório de Tecnologia de Sementes do CCA/UFES, até 14 $5 \%$. Posteriormente, subamostras de 200 sementes foram escarificadas com lixa d'água número 220 e colocadas para embeber em água destilada por 24 horas. Após esse período, todas as sementes (intactas e escarificadas), num total de 300 sementes, foram desinfestadas em álcool a $70 \%$ por 30 segundos e, em seguida, com hipoclorito de sódio a $1 \%$ durante 10 minutos. Imediatamente após a desinfestação, as sementes foram levadas para câmara de fluxo laminar, lavadas com água esterilizada para retirar o excesso de hipoclorito de sódio. Em duas subamostras de 100 sementes foram retirados os tegumentos (80) e eixo embrionários (80) com auxílio de pinça e bisturi, que foram novamente desinfestados com hipoclorito de sódio $0,5 \%$ e em seguida lavados com água esterilizada. O cultivo in vitro foi feito em meio MS completo e solidificado com ágar da marca Lafan, sendo o $\mathrm{pH}$ aferido para 5,7 $\pm 0,1$ antes da autoclavagem. Posteriormente foi distribuído em tubos de ensaio de $25 \times 150 \mathrm{~mm}\left(10 \mathrm{~mL} \mathrm{tubo}^{-1}\right)$ e os mesmos foram tapados com papel alumínio e esterilizados em autoclave à temperatura de $121^{\circ} \mathrm{C}$ e pressão de $1,05 \mathrm{kgf} \mathrm{cm}^{-2}$, durante 20 minutos e levados para sala de crescimento para que esfriassem antes da inoculação. Foram feitos os seguintes testes: germinção in vitro - realizada com a inoculação das sementes intactas (SI), sementes sem tegumento (SST) e eixos embrionários (E) nos tubos, que foram novamente tapados com papel alumínio, vedados com parafilme e mantidos em sala de crescimento à temperatura constante de $27 \pm 2^{\circ} \mathrm{C}$ e fotoperíodo de 16 horas sob lâmpadas fluorescentes do tipo luz do dia fornecendo 1.000 Lux de intensidade 
luminosa. As avaliações foram feitas diariamente. O critério de avaliação adotado foi a protrusão da raiz primária com $2 \mathrm{~mm}$ de comprimento para sementes intactas e sem tegumento e desenvolvimento da radícula com extensão igual ou maior que $2 \mathrm{~mm}$ para eixos embrionários. Após 30 dias da implantação do experimento, as sementes que não germinaram e os eixos que não se desenvolveram foram avaliados quanto à viabilidade, pela imersão em solução de cloreto de 2,3,5 trifenil tetrazólio, a $30^{\circ} \mathrm{C}$ por 24 horas. Após esse período o material foi lavado em água corrente, identificadas e computadas as porcentagens de sementes dormentes (SD), sementes mortas (SM) e eixos embrionários mortos (EM); classificação das plântulas normais e anormais - realizada ao final do experimento, 30 dias após a inoculação. As plântulas foram classificadas conforme as Regras para Análise de Sementes (Brasil, 1992); massa fresca e seca das plântulas - foram determinadas utilizando-se as plântulas classificadas como normais no final do teste de germinação.

O delineamento experimental foi o inteiramente casualizado em esquema fatorial A x B, com quatro repetições de cinco tubos por tratamento, sendo utilizadas para o fator A, três tratamentos: sementes intactas (SI), sementes sem tegumento (SST) e eixos embrionários (E) e para o fator quatro níveis de ágar (4, 6, 8 e 10g.L $\left.\mathrm{L}^{-1}\right)$ em meio básico MS. Os resultados obtidos foram submetidos à análise de regressão polinomial de ordem 2 .

\section{RESULTADOS E DISCUSSÃO}

A variação nas concentrações de ágar no meio de cultivo influenciou a germinação das sementes e o desenvolvimento de eixos embrionários (Figura 1). Verificou-se, pelos resultados obtidos, que sementes intactas (SI) apresentaram aumento gradativo na germinação à medida que se aumentou a concentração de ágar no meio de cultura, culminando com cerca de $40 \%$ de sementes germinadas, conforme pode ser observado pela aplicação da análise de regressão. Comportamento similar foi observado nos eixos embrionários (E), onde a porcentagem de desenvolvimento também aumentou gradativamente, atingindo $60 \%$. Para as sementes sem tegumento (SST), a germinação atingiu $80 \%$ em meio de cultura com $4 \mathrm{~g} . \mathrm{L}^{-1}$ de ágar, caindo progressivamente na medida em que se aumentou a concentração deste agente solidificante no meio, conforme pode ser visto pela aplicação da análise de regressão. A menor porcentagem de germinação nas sementes intactas pode ser explicada pela resistência que o tegumento oferece à absorção de água e, conseqüentemente, à

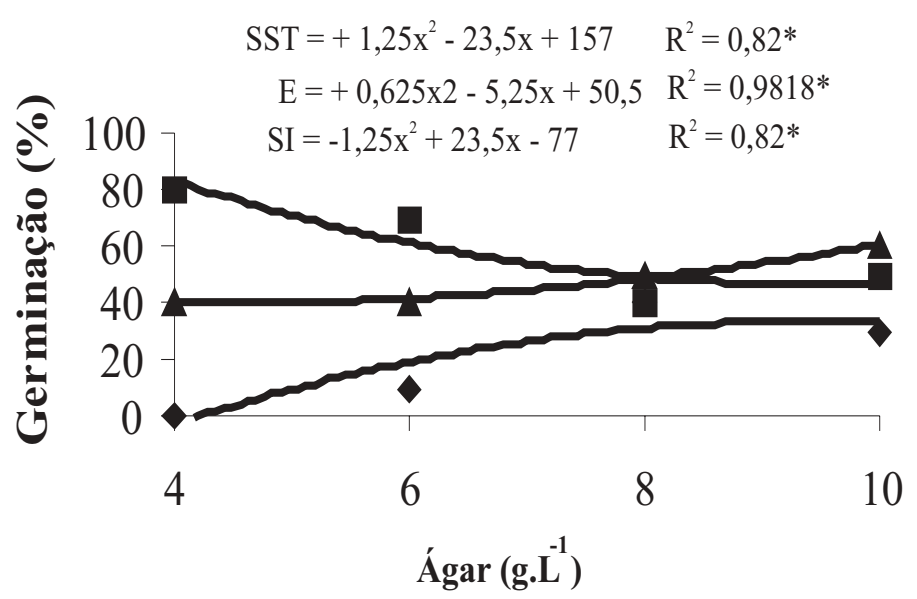

- Semente intacta (SI)

Semente sem tegumento (SST)

$\Delta$ Eixo embrionário (E)

FIGURA 1. Germinação (\%) de sementes intactas, sementes sem tegumento e desenvolvimento de eixos embrionários de urucu (Bixa orellana L.) em diferentes concentrações de ágar.

germinação, fato comprovado pelo resultado nas sementes sem tegumento, onde a germinação atingiu valores mais altos em concentrações de até 8g.L -1 $^{-1}$ de ágar. Coelho et al. (2001) verificaram que para a condição in vitro, as sementes de Pterodon pubescens sem tegumento apresentaram-se como melhor método para superação de dormência. A remoção ou injúria do tegumento por escarificação química ou mecânica, além de aumentar a permeabilidade à água, pode ainda levar a outras mudanças tais como: aumento da sensibilidade à luz e temperatura, permeabilidade a gases, remoção de promotores ou inibidores, afetando o metabolismo da semente e conseqüentemente a sua dormência (Khan, 1977). Por outro lado, o aumento na concentração de ágar no meio de cultura, até $10 \mathrm{~g} . \mathrm{L}^{-1}$, favoreceu o desenvolvimento de eixos embrionários, atingindo cerca de $60 \%$, conforme pode ser observado pela Figura 1.

A análise de germinação mostrou, também, que os eixos embrionários apresentaram maiores porcentagens de plântulas normais (Brasil, 1992), onde se verificou bom desenvolvimento linear da raiz primária, com presença de raízes secundárias; crescimento e diferenciação do hipocótilo, longo e cilíndrico, com coloração rosada na base e esverdeada em direção aos cotilédones; os cotilédones apresentaram-se livres, planos, evidentes, abertos, em expansão e verdes, com crescente aumento à medida que se acrescentou ágar ao meio de cultivo, 
conforme pode ser visto pela análise de regressão na Figura 2. Esses resultados sugerem que o sistema adotado para desenvolvimento dos eixos embrionários foi satisfatório e que o método de desinfestação também foi eficiente no controle de patógenos e não interferiu no desenvolvimento dos eixos. Resultados similares foram encontrados por Carvalho et al. (2005).

A Figura 3 evidencia que as sementes intactas não apresentaram plântulas anormais na concentração de $4 \mathrm{~g} . \mathrm{L}^{-1}$ de ágar. Entretanto, não se verificou germinação das sementes. Castellani et al. (2001), trabalhando com caracterização morfológica de frutos e sementes de xylópia, não obtiveram germinação das sementes quando a semeadura foi feita em meio de cultura. $\mathrm{O}$ aumento da concentração de ágar no meio de cultivo para 6,8 e $10 \mathrm{~g} . \mathrm{L}^{-1}$ determinou aumento na porcentagem de plântulas anormais para 10 e 20\%, cujas características evidenciadas nas plântulas foram: ausência de raiz primária, ou quando presente apresentava bifurcação; ocorrência de plântulas raquíticas e plântulas deterioradas. Plântulas normais e anormais com características similares às encontradas nesse trabalho foram descritas por Pereira (1995). Nas sementes sem tegumento, os resultados obtidos foram contrários, ou seja, nas concentrações mais baixas de ágar 4 e 6 g.L. ${ }^{-1}$, houve maior ocorrência de plântulas anormais, atingindo valores de 80 e $60 \%$, respectivamente, tendo esses valores reduzidos para 30 e $20 \%$, quando as concentrações de ágar no meio de cultivo foram aumentadas para 8 e

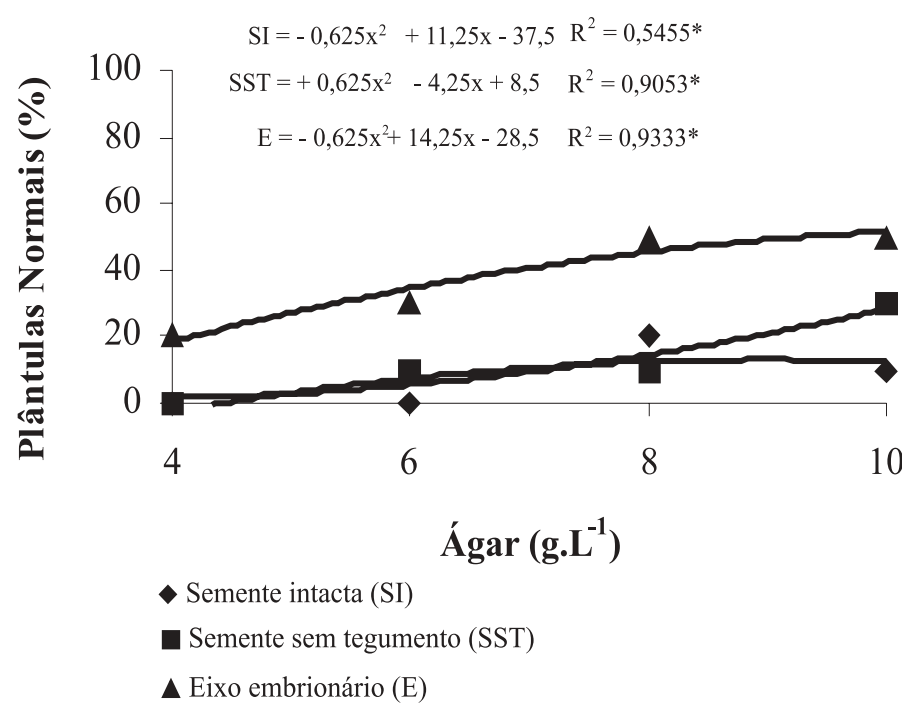

FIGURA 2. Plântulas normais (\%) na germinação de sementes intactas, sementes sem tegumento e desenvolvimento de eixos embrionários de urucu (Bixa orellana L.) em diferentes concentrações de ágar.

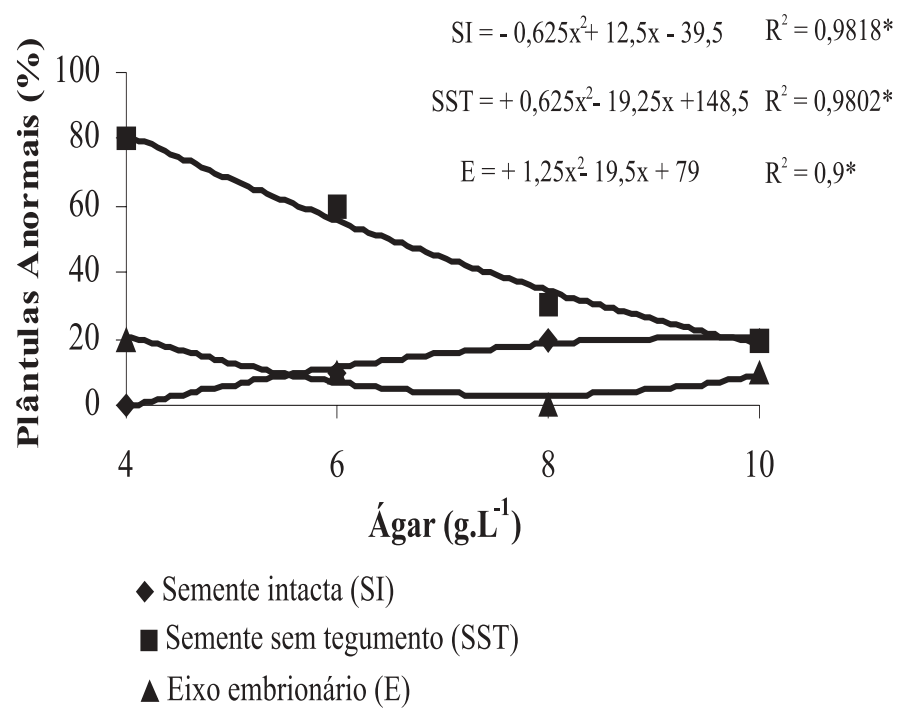

FIGURA 3. Plântulas anormais $(\%)$ na germinação de sementes intactas, sementes sem tegumento e desenvolvimento de eixos embrionários de urucu (Bixa orellana L.) em diferentes concentrações de ágar.

10g. $\mathrm{L}^{-1}$, respectivamente. Os eixos embrionários apresentaram valores baixos de plântulas anormais 10,0 e $10 \%$ em meios solidificados com 6, 8 e 10g.L ${ }^{-1}$ de ágar, respectivamente, tendo as plântulas se desenvolvido melhor também nesses meios. Entretanto, a concentração de $4 \mathrm{~g} \cdot \mathrm{L}^{-1}$ de ágar proporcionou valores elevados de plântulas anormais (20\%).

Pode-se observar pela Figura 4, que a massa fresca das plântulas oriundas de sementes intactas teve valores crescentes em concentrações de até $8 \mathrm{~g} \cdot \mathrm{L}^{-1}$ de ágar, decrescendo à medida que essa concentração aumentou, conforme mostra a análise de regressão. A explicação para esse fenômeno pode estar associada ao fato de que em meio aquoso há maior absorção de água pelos tecidos dos explantes (Willians e Leopold, 1989). Comportamento contrário foi observado nas sementes sem tegumento, onde ocorreu aumento gradativo na massa fresca das plântulas à medida que se adicionou o ágar no meio de cultivo, como mostra a análise de regressão. No desenvolvimento de eixos embrionários, pode-se observar pouca variação na massa fresca das plântulas, em função do aumento de ágar ao meio de cultivo, como se verifica pela análise de regressão. Pasqual et al. (2002) estudando o cultivo in vitro de embriões imaturos de tangerineira, obtiveram maiores valores de massa fresca em meios de cultivo na ausência de ágar ou em baixa concentração do mesmo, ocorrendo uma redução nessa característica à medida que se acrescentou ágar ao meio. 


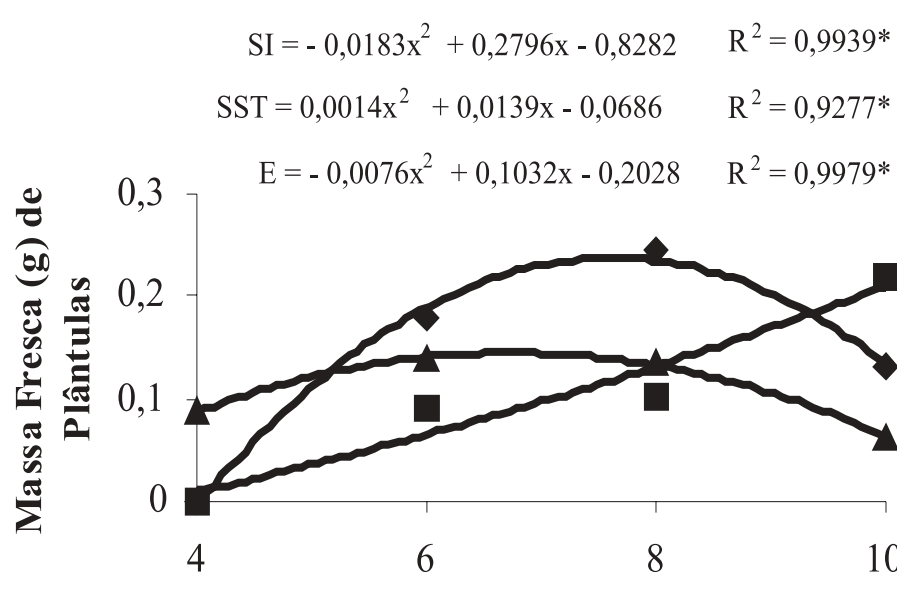

Ágar (g.L $\left.{ }^{-1}\right)$

FIGURA 4. Massa fresca (g) de plântulas normais de sementes intactas, sementes sem tegumento e eixos embrionários de urucu (Bixa orellana L.) em diferentes concentrações de ágar.

A massa seca das plântulas apresentou variações entre os tipos de sementes e/ou eixos embrionários e dentre as concentrações de ágar utilizadas no meio de cultivo (Figura 5). Em plântulas oriundas de sementes sem tegumento, a massa seca foi crescente com o aumento da concentração de ágar no meio de cultura. Esse resultado pode ser atribuído ao fato de que maiores concentrações de ágar no meio de cultivo favorecem a absorção de minerais e, conseqüentemente, maior acúmulo de biomassa, culminando com maior massa seca. De acordo com Salisbury e Ross (1994), maior matéria seca de plantas in vivo, significa maior acúmulo de fotoassimilados e maior absorção de minerais. Peixoto e Pasqual (1991), estudando a influência do $\mathrm{pH}$ e do ágar na absorção in vitro de nutrientes em brotações de videira (Vitis spp), demonstraram que após 45 dias de cultivo ocorreram variações na absorção dos nutrientes $\mathrm{K}, \mathrm{S}, \mathrm{Fe}, \mathrm{Mn}, \mathrm{Ca}, \mathrm{Mg}$, $\mathrm{P}, \mathrm{Zn}$ e $\mathrm{Cu}$ em função dos diferentes $\mathrm{pH}$ e concentrações de ágar utilizados $\left(3,5,7,0\right.$ e 10,5g.L $\left.\mathrm{L}^{-1}\right)$. O contrário foi observado em sementes intactas e eixos embrionários, onde ocorreu uma queda na massa seca das plântulas, com o aumento da concentração de ágar no meio de cultivo. Resultados semelhantes foram encontrados por Pasqual et al. (2002), onde houve redução na massa de brotações secas com o aumento da concentração de ágar no meio de cultivo. Brouwer (1962), em uma revisão sobre distribuição de massa seca nas

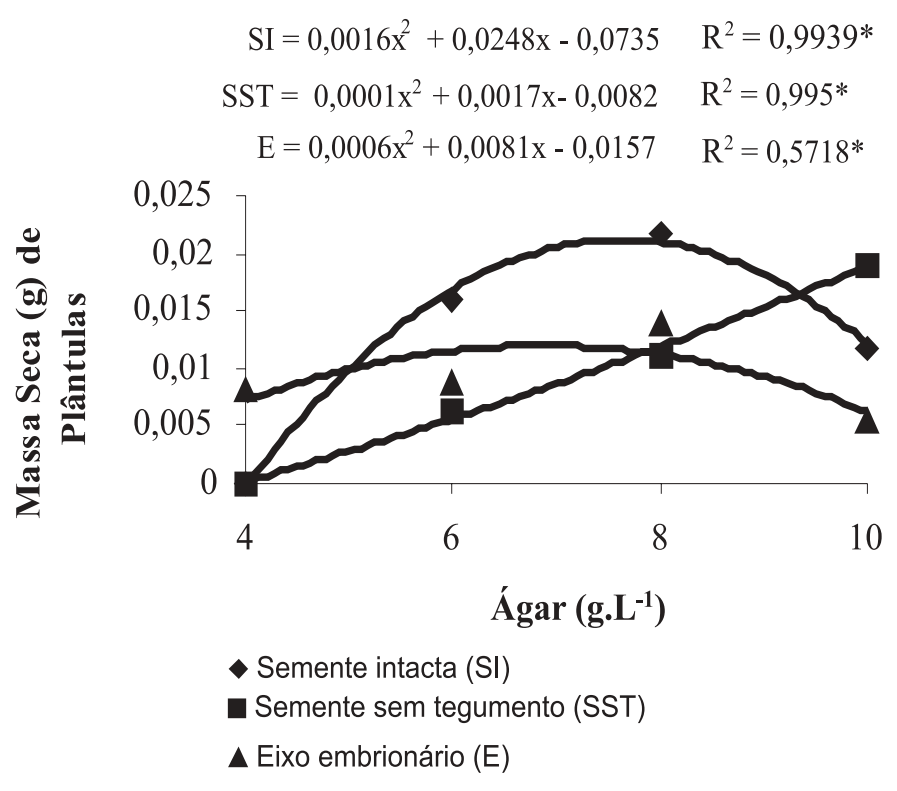

FIGURA 5. Massa seca (g) de plântulas normais de sementes intactas, sementes sem tegumento e eixos embrionários de urucu (Bixa orellana L.) em diferentes concentrações de ágar.

diferentes partes da planta afirma que uma parte dessas correlações é fixada geneticamente e, dentro desses limites, as condições externas podem exercer um efeito modificador. De acordo com Benincasa (1988), cerca de 90\% de matéria seca acumulada pelas plantas, ao longo de seu crescimento, são resultantes da atividade fotossintética e o restante depende da absorção de minerais do meio.

As porcentagens de sementes dormentes (SD), sementes mortas (SM) e eixos embrionários mortos (EM), verificadas no final desse experimento, encontram-se na Figura 6. Em concentrações de até $4 \mathrm{~g} . \mathrm{L}^{-1}$ de ágar, ocorreu $100 \%$ de sementes dormentes, verificadas apenas em sementes intactas, cujos valores decaíram progressivamente à medida que se aumentou a concentração de ágar no meio de cultivo atingindo um valor mínimo de $60 \%$ em 8g.L $\mathrm{L}^{-1}$ de ágar (Figura 6A). Com relação às sementes mortas, cuja presença foi detectada somente nas sementes sem tegumento, o comportamento foi contrário. $\mathrm{O}$ aumento da concentração de ágar no meio de cultivo, determinou aumento, cujos valores oscilaram entre $20 \%$ em 4g.L ${ }^{-1}$ e $60 \%$ em 8g.L ${ }^{-1}$ de ágar (Figura 6B). No caso de eixos embrionários mortos, o comportamento foi semelhante ao das sementes dormentes, ou seja, os valores decaíram à medida que se aumentou a concentração de ágar no meio de cultivo, com um máximo de $60 \%$ em 4 g.L - $^{-1}$ de ágar e um mínimo de $40 \%$ em 10g.L $\mathrm{L}^{-1}$ de ágar (Figura 6C). 

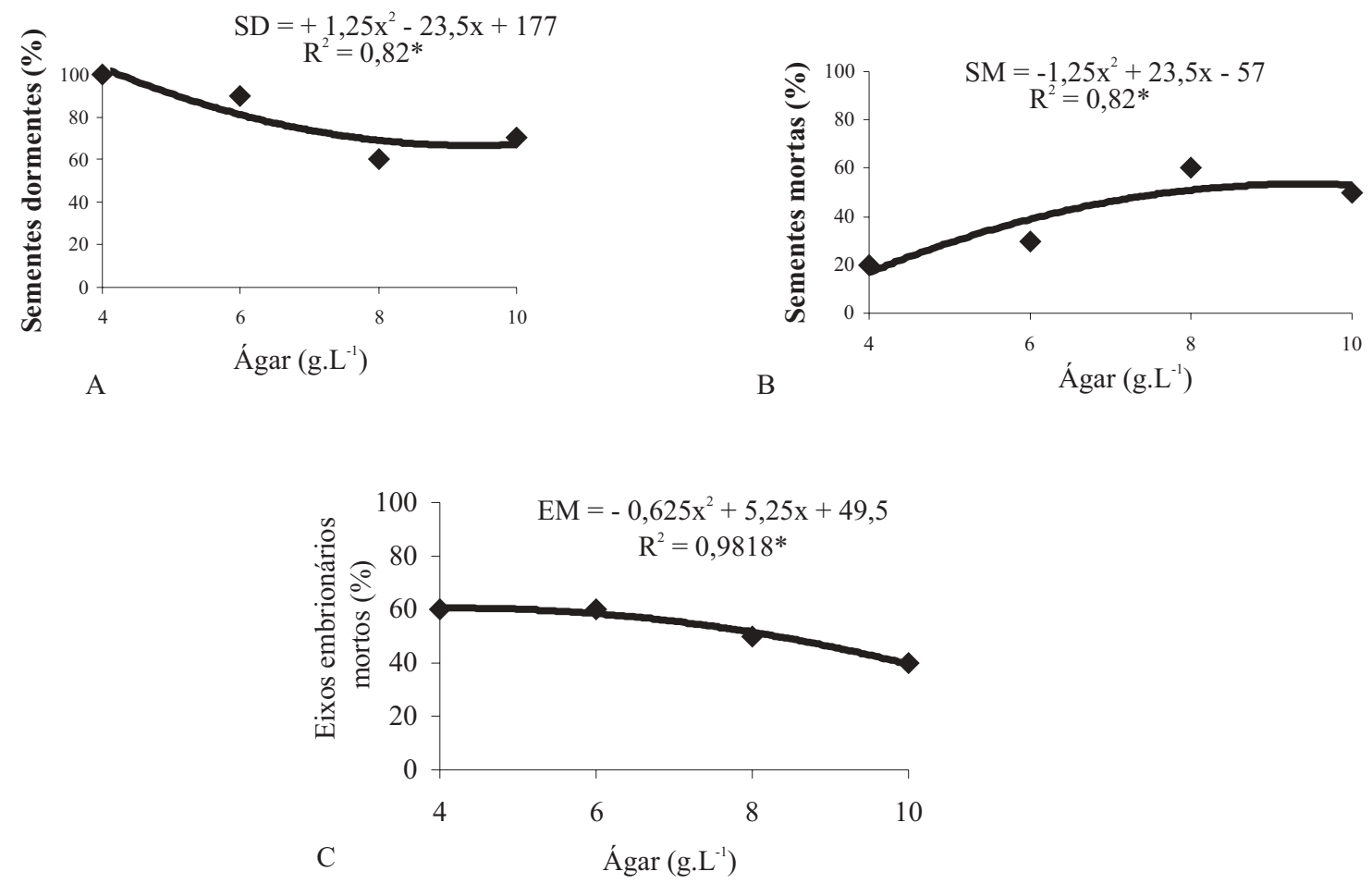

FIGURA 6. A - Sementes dormentes (\%), B - Sementes mortas (\%), C-Eixos embrionários mortos (\%) de urucu (Bixa orellana L.) em diferentes concentrações de ágar.

\section{CONCLUSÕES}

Para a condição in vitro sementes de urucu sem tegumento apresentam maior porcentagem de germinação em relação às intactas, apresentando-se como melhor método para superar a dormência.

O desenvolvimento in vitro de eixos embrionários de urucu é melhor em meio MS com concentração de $10 \mathrm{~g} . \mathrm{L}^{-1}$.

A concentração de ágar no meio MS favorece o desenvolvimento in vitro de plântulas normais.

\section{AGRADECIMENTOS}

Ao CNPq pela concessão de bolsa ao primeiro autor.

\section{REFERÊNCIAS}

AMARAL, L.I.V.; PEREIRA, M.F.D.A.; CORTELAZZO, A.L. Quebra de dormência em sementes de Bixa orellana. Revista Brasileira de Fisiologia Vegetal, São Paulo, v.7, n.2, p.151-157, 1995.

BENINCASA, M.M.P. Análise de crescimento de plantas (noções básicas). Jaboticabal: FUNEP, 1988. 42p.
BEWLEY, J.D.; BLACK, M. Seeds: physiology of development and germination. 2.ed. New York and London: Plenum Press, 1994. 445p.

BRASIL. Ministério da Agricultura e Reforma Agrária. Regras para análise de sementes. Brasília: SNDA/DNDV/CLAV, 1992. $365 \mathrm{p}$.

BROUWER, R. Distribution of dry matter in the plant. Netherlands Journal of Agricultural Science, Wageningen, v.10, n.5, p.361$376,1962$.

CALDAS, L.S.; HARIDASAN, P.; FERREIRA, M.E. Meios nutritivos. In: TORRES, A.C.; CALDAS, L.S.; BUSO, J.A (Ed.). Cultura de tecidos e transformação genética de plantas. Brasília: EMBRAPA; CBAB, 1998. p.87-132.

CARVALHO, J.F.R.P.; CARVALHO, C.R.; OTONI, W.C. Regeneração in vitro de urucum (Bixa orellanaL.) a partir de diferentes tipos de explantes. Revista Árvore, Viçosa, v.29, n.6, p.887-895, 2005.

CASTELlANI, E.D.; DAMIÃO-FILHO, C.F.; AGUIAR, I.B. Caracterização morfológica de frutos e sementes de espécies arbóreas do gênero Xylopia (Annonaceae). Revista Brasileira de Sementes, Brasília, v.23, n.1, p.205-211, 2001.

CHOPRA, R.N.; KAUR, H. Embryology of Bixa orellana Linn. Phytomorphology, New Delhi, v.15, p.211-215, 1965.

COELHO, M.C.F; PINTO, J.E.B.P.; MORAIS, A.R.; CID, L.P.B.; LAMEIRA, O.A. Germinação de sementes de sucupira-branca (Pterodon pubescens (Benth.) Benth.) in vitro e ex vitro. Ciência 
e Agrotecnologia, Lavras, v.25, n.1, p.38-48, 2001.

GRATTAPAGLIA, D.; MACHADO, M. A. Micropropagação. In: TORRES, A. C.; CALDAS, L. S.; BUSO, J. A. (Ed.) Cultura de tecidos e transformação genética de plantas. v.1. Brasília: EMBRAPA-SPI/EMBRAPA-CNPH, 1998. p.183-260.

KHAN, A.A., Seed dormancy: changing concepts and theories. In: KHAN, A.A. (Ed.) The physiology and biochemistry of seed dormancy and germination. New York: North - Holland Publishing Company, 1977. 447p.

MACIEL, A.L.R.; SILVA, A.B.; PASQUAL, M. Aclimatização de plantas de violeta (Saintpaulia ionantha Wendl) obtidas in vitro: efeitos do substrato. Ciência e Agrotecnologia, Lavras, v.24, n.1, p.9-12, 2000.

MURASHIGE, T.; SKOOG, F. A revised medium for rapid growth and bioassays with tobacco tissue cultures. Physiologia Plantarum, Copenhagen, v.15, n.3, p.473-497, 1962.

MURASHIGE, T. Plant propagation through tissue cultures. Annual Review of Plant Physiology, Columbus, v.25, p.135-166, 1974.

PASQUAL, M.; PINTO, J.E.B.P. Cultura de embriões. Piracicaba: ESALQ, 1988. 13p.

PASQUAL, M.; FINOTTI, D.R.; DUTRA, L.F.; CHAGAS, E.A;
RIBEIRO, L.O. Cultivo in vitro de embriões imaturos de tangerineira "Poncã" em função do $\mathrm{pH}$ e da concentração de ágar. Revista Brasileira de Agrociência, Pelotas, v.8, n.3, p.199$202,2002$.

PEIXOTO, P.H.P.; PASQUAL, M. Influência do pH e do ágar na absorção in vitro de nutrientes em brotações de videira (Vitis spp.). In: CONGRESSO BRASILEIRO DE FISIOLOGIA VEGETAL, 3, 1991, Viçosa, Anais..., SBFV, 1991. p.81.

PEREIRA, T.S. Caracterização de plântulas de Bixa orellana L. urucu (Bixaceae). Revista Brasileira de Sementes, Brasília, v.17, n.2, p.243-248, 1995.

RAMALHO, R.S.; PINHEIRO, A.L.; DINIZ, G.S. Informações básicas sobre a cultura e utilização do urucu (Bixa orellana L.) Informe Técnico, Viçosa, v.59, n.8, p.1-22.

ROLSTON, M.P. Water impermeable seed dormancy. The Botanical Review, New York, v.44, n.3, p.365-396, 1978.

SALISBURY, F.B.; ROOS, C.W. Fisiologia vegetal. México: Iberoamérica, 1994. 759p.

TAIZ, L; ZEIGER, E. Fisiologia Vegetal. 3.ed. Porto Alegre: Artmed, 2004.719p.

WILLIANS, R.J.; LEOPOLD, A.C. The glassy state in corn embryos. Plant Physiology, Rockville, v.89, n.3, p.977-981, 1989. 